\title{
Mapeamento da Vegetação e do uso do solo no Centro de Diversidade Vegetal de Cabo Frio, Rio de Janeiro, Brasil ${ }^{1}$
}

\author{
Claudio Belmonte de Athayde Bohrer ${ }^{2,6}$, Heloisa Guinle Ribeiro Dantas ${ }^{3}$, \\ Felipe Mendes Cronemberger ${ }^{4}$, Raul Sanchez Vicens ${ }^{2}$ \\ \& Sandra Fernandes de Andrade ${ }^{5}$
}

\begin{abstract}
RESUMO
(Mapeamento da vegetação e do uso do solo no Centro de Diversidade Vegetal de Cabo Frio, Rio de Janeiro, Brasil) A região de Cabo Frio é reconhecida como um importante centro de diversidade vegetal (CDVCF) da Região Neotropical, devido à presença de diversos taxa endêmicos e comunidades vegetais singulares, o que pode ser relacionado tanto ao clima relativamente seco quanto à heterogeneidade do ambiente físico. Embora diversos estudos realizados na região tenham produzido informações importantes sobre a estrutura e composição florística de algumas comunidades vegetais, existe ainda uma considerável lacuna na classificação e definição dos tipos de vegetação bem como de sua distribuição espacial. Este trabalho tem como objetivo analisar e descrever os tipos de vegetação da região e sua relação com o ambiente físico, através do mapeamento da cobertura vegetal e uso do solo, baseado na análise integrada de imagens de satélite, fotografias aéreas, mapas temáticos e dados pontuais provenientes de levantamentos estruturais e florísticos e trabalhos de campo, com apoio do processamento digital de imagens e de sistema de informações geográficas. Os resultados são apresentados acompanhados de um mapa da vegetação e uso do solo da área do CDVCF, que poderá ser utilizado como base para novos estudos florísticos e ecológicos, para estudos da dinâmica da paisagem e para apoio ao planejamento ambiental e a conservação da biodiversidade da região. Palavras-chave: cobertura vegetal, uso do solo, relação vegetação-ambiente físico.
\end{abstract}

\section{Abstract}

(Vegetation and land cover mapping of the Cabo Frio Centre of Plant Diversity, Rio de Janeiro, Brazil) The Cabo Frio region has been nominated an important Centre of Plant Diversity of the Neotropical Region due to the presence of several endemic taxa and unique plant communities, which are related to both a dry climate and a heterogeneous physical environment. Although previous studies have provided important floristic and structural information on vegetation types, there is still considerable uncertainty about the spatial distribution, extent and variation in vegetation cover, as well as the classification and definition of these types. This work aims to provide an analysis of the region's vegetation and its relationship to the physical environment, through vegetation and land cover mapping, based on an integrated analysis of satellite images and aerial photographs, thematic maps, point data from previous floristic and structural surveys and field work, supported by digital image processing and geographic information system software. These results are accompanied by a vegetation and land cover map of the entire area, thus providing a basis for further ecological studies, conservation and land use planning and monitoring and landscape dynamics analyses. Key words: vegetation, land cover, vegetation-physical environment relationships.

\section{INTRODUÇÃO}

A vegetação é parte integrante da paisagem e serve como um indicador de outros atributos do ambiente e de suas variações no espaço. Contribui também para o fornecimento de diversos produtos e serviços ecossistêmicos, alimentos, materiais de construção e abrigo, combustível, conservação do solo, recursos hídricos e da vida silvestre.

Mapas de vegetação mostram a localização, extensão e distribuição dos tipos de vegetação de uma dada região, apresentando um inventário

Artigo recebido em 05/2008. Aceito para publicação em 02/2009.

${ }^{1}$ Este trabalho contou com o apoio financeiro da FAPERJ.

${ }^{2}$ Departamento de Geografia, Instituto de Geociências, Universidade Federal Fluminense, Campus Praia Vermelha, Boa Viagem, Niterói, RJ, 24210-340, Brasil

${ }^{3}$ Arquiteta Paisagista MSc.

${ }^{4}$ Programa de Pós-Graduação em Ciência Ambiental, Instituto de Geociências, Universidade Federal Fluminense, Niterói, RJ. ${ }^{5}$ Programa de Pós-Graduação em Geoquímica, Instituto de Química, Universidade Federal Fluminense, Niterói, RJ.

${ }^{6}$ Autor para correspondência: bohrer@vm.uff.br 
das comunidades vegetais existentes. Com isso gera-se uma como ferramenta para a análise das relações entre a vegetação e o meio físico e como padrões de referência no monitoramento das mudanças temporais na vegetação, fornecendo embasamento científico ao planejamento do uso da terra (Bohrer 2000). As suas características variam de acordo com a escala cartográfica, os métodos e os tipos de imagens utilizados, que determinam a definição dos padrões passíveis de serem mapeáveis.

A vegetação natural geralmente varia continuamente no espaço, exceto em caso de descontinuidade geológica, histórica ou ambiental (Austin 2005). Portanto, os limites entre os diferentes tipos de vegetação são geralmente arbitrários e influenciados pela escolha das características nas quais se baseia a sua classificação (Küchler 1988b). Os sistemas de classificação da vegetação podem ser agrupados em dois tipos básicos (Whittaker 1978): fisionômico-estrutural, baseado nas formas de vida ou de crescimento dominantes, e florístico, baseado nas espécies ocorrentes. A fisionomia da vegetação é definida pelos tipos estruturais ou formas de crescimento dominantes ou comuns nas comunidades, definindo a aparência ou aspecto geral da vegetação (Beard 1978). A estrutura está relacionada ao padrão de distribuição das espécies na comunidade vegetal, definida pelos três componentes: vertical (estratificação), horizontal (distribuição espacial dos indivíduos) e pela abundância de cada espécie (Kent \& Coker 1992; Küchler 1988a). A maioria dos sistemas fisionômicos utiliza o conceito de formação, considerada como um tipo de comunidade definido pelas formas de crescimento dominantes e pelas características principais do ambiente (Beard 1978).

De acordo com Veloso \& Goes-Filho (1982), a evolução da classificação da vegetação brasileira pode ser traçada desde Martius em 1840, que definiu cinco regiões florísticas denominadas com o nome de divindades gregas, delineadas em mapa fitogeográfico anexado à Flora brasiliensis por Grisebach, em 1858. A vegetação da faixa costeira foi denominada
Dryades. Gonzaga Campos propôs em 1926 uma primeira classificação baseada no aspecto fisionômico da vegetação, reconhecendo três grandes grupos - campos, caatingas e florestas, definindo duas divisões da floresta atlântica: florestas das encostas e dos pinheiros (Veloso \& Góes-Filho 1982). Azevedo (1950) estabeleceu um sistema fisionômico-ecológico dividindo a vegetação brasileira em três grandes formações: florestais, com seis subdivisões; arbustivas e herbáceas; e complexas, onde incluiu as formações litorâneas. Rizzini (1997) volta a identificar dois grandes grupos de floresta, amazônica e atlântica, subdivida em dois conjuntos heterogêneos, um dos quais sem tipos próprios de vegetação, onde se inclui o Complexo de Restinga.

Beard (1946, 1955) desenvolveu um sistema de classificação para a América tropical baseado em características fisionômicas, utilizando também aspectos ecológicos, relacionando a fisionomia da vegetação a gradientes ambientais, com as formações definidas como estágios reconhecíveis ao longo de um gradiente contínuo. A UNESCO propôs um sistema fisionômico global de classificação (Ellenberg \& Mueller-Dombois 1967), posteriormente aperfeiçoado para utilização no mapeamento da vegetação mundial na escala 1:1.000.000 (UNESCO 1973), que emprega o conceito de formas de vida de Raunkiaer, modificado e expandido, além de aspectos ambientais considerados importantes.

O mapeamento da vegetação do país efetuado pelo Projeto Radambrasil evoluiu para um sistema de classificação desenvolvido a partir desta proposta, baseado numa hierarquia de região ecológica, formação e subformação, de acordo com a escala e o nível de detalhe utilizado, sendo a região fitoecológica entendida como uma "área de florística típica e de formas biológicas características, que se repete dentro de um mesmo clima" (Veloso \& Góes-Filho 1982, pág 32). De acordo com este sistema, posteriormente revisado (Veloso et al. 1991), a floresta ombrófila densa recobre as áreas costeiras úmidas sem estação seca pronunciada, e a floresta estacional semidecidual ocupa as 
áreas interioranas com ocorrência de três ou mais meses secos. As formações pioneiras, incluindo restingas, manguezais e campos inundáveis, ocorrem nas planícies quaternárias ao longo de toda a zona costeira (IBGE 1993).

Ule (1967) diferenciou a vegetação da região de Cabo Frio em diversos tipos de comunidades vegetais: comunidade halófita sobre dunas mais expostas à salinidade; restingas de Ericaceae (vegetação arbustiva pouco densa), de Myrtaceae (arbustiva densa com maior riqueza de espécies), e de Clusia (vegetação mais alta e densa); e as matas paludosas e de restinga. Rizzini (1997) dividiu a região em litoral rochoso, limoso e arenoso, este por sua vez composto por dunas móveis e fixas, com vegetação herbáceo-arbustiva (thicket) distinta da restinga típica (vegetação arboriforme sobre areia mais compactada) e da mata de restinga, com dossel entre 8 e 12 metros.

Araujo \& Henriques (1984) dividem as restingas do Rio de Janeiro em doze tipos de comunidades vegetais, de acordo com características fisionômicas, ecológicas e florísticas, adaptando algumas das classes propostas por Ule (1967). Sá (1992) usou os termos mata paludosa, para a vegetação arbórea florestal sobre áreas periódica ou permanentemente alagadas, e floresta seca, para as áreas arenosas planas ou de relevo suave, em Saquarema. Farág (1999) caracterizou a vegetação arbórea sobre planície arenoargilosa em Búzios como mata semicaducifólia.

O mapeamento da vegetação da região pelo Projeto Radambrasil (Ururahy et al. 1983) considerou a relação entre a fisionomia e o clima, a partir da relação ombrotérmica $\mathrm{P}>$ 2T (Walter 1986), para separar as áreas com cobertura florestal perene e decidual. A floresta estacional semidecidual, que alcança o litoral na região da desembocadura do rio Paraíba do Sul, recobre as planícies e colinas da região de Cabo Frio. A vegetação sobre os morros costeiros foi considerada como uma disjunção fisionômica-ecológica da caatinga nordestina e classificada como estepe arbórea, termo posteriormente substituído por savana-estépica florestada (Veloso et al. 1991), em função dos baixos índices pluviométricos e da fisionomia, caracterizada por alta percentagem de espécies suculentas e lenhosas deciduais e espinhosas com microfolia, associada a solos eutróficos pouco desenvolvidos (Ururahy et al. 1987).

Em uma análise dos padrões de distribuição das leguminosas arbóreas do estado, Lima (2000) categoriza as formações arbóreas da região como florestas de planície não-inundada, submontana e de planície sobre depósito marinho. Araujo (2000) classificou a vegetação das restingas da região de acordo com a posição topográfica em relação ao mar e a fisionomia, utilizando as denominações mata seca, mata inundada e vegetação arbustiva fechada, aberta e herbácea.

Um novo mapeamento do uso do solo e cobertura vegetal do estado, com base em imagens Landsat TM (CIDE 2000), adotou o sistema de classificação do IBGE, com a utilização de termos de fácil entendimento e de classes de cobertura adicionais. O trabalho foi posteriormente atualizado, com uma melhor definição da legenda e de sua relação com a classificação do IBGE (Bohrer 2003a). Foi analisada também a evolução da cobertura arbórea por município, a partir da comparação com cartas planialtimétricas (de 1956-69), registrando um aumento de 4,8\% em Saquarema e diminuição de $20,8 \%$ em Cabo Frio, com uma tendência geral de redução da cobertura arbórea da região (Bohrer 2003b). Outros trabalhos em escala de detalhe, com uso de fotografias aéreas e imagens orbitais de alta resolução espacial, incluem o mapeamento da vegetação na Praia Grande, em Arraial do Cabo (Araujo et al. 2004), e do município de Armação dos Búzios (Dantas et al. 2009, neste volume).

De modo geral, a vegetação da região reflete a sua especificidade climática associada à heterogeneidade física, apresentando uma grande diversidade fisionômica e florística e alto grau de endemismos, estando aparentemente condicionada também pela história paleoevolutiva, mantendo uma vegetação remanescente dos períodos glaciais do Pleistoceno (Ab'Saber 1992; Araujo et al. 1998). Devido ao conjunto 
destes fatores, a região foi apontada como Centro de Diversidade Vegetal de Cabo Frio CDVCF (Araujo 1997).

O objetivo deste trabalho consiste na elaboração de mapa da cobertura vegetal e do uso do solo atual na área do Centro de Diversidade Vegetal de Cabo Frio, mostrando a extensão atual das áreas de vegetação natural remanescente e sua relação com o ambiente físico e a ação antrópica.

\section{Material e Métodos}

\section{Descrição da área de estudo}

A área delimitada como Centro de Diversidade Vegetal de Cabo Frio recobre uma extensão aproximada de $1562 \mathrm{~km}^{2}$, abrangendo oito municípios do estado do Rio de Janeiro: Maricá, Saquarema, Araruama, Iguaba Grande, São Pedro da Aldeia, Cabo Frio, Arraial do Cabo e Armação dos Búzios (Fig. 1). A região caracteriza-se pela diversidade de ambientes, resultante da sua evolução físico-geográfica.
Processos intrusivos, tectônicos e deposicionais, associados à ação de processos erosivos, fluviais, lacustres e costeiros, respondem pela diversidade litológica e de formas de relevo da região, que, combinada com a alternância de condições climáticas e a diferenciação espacial nas condições de umedecimento, resultaram na diversificação dos tipos de solos e das fisionomias da vegetação.

O rio São João constitui o limite norte do CDVCF, que abrange também as bacias do rio Una e das lagoas de Araruama, Saquarema, Jaconé e Jacarepiá. Ocorrem ainda diversas lagoas menores, perenes ou temporárias, importantes para a dinâmica hidrológica e a vegetação das áreas mais baixas (Bidegain \& Bizerril 2002; CILSJ 2002).

A região abrange dois domínios morfoestruturais (RADAMBRASIL 1983): a faixa de dobramentos remobilizados e os Depósitos Sedimentares. O relevo movimentado é oriundo dos falhamentos e dobramentos de uma litologia cristalina que remonta ao

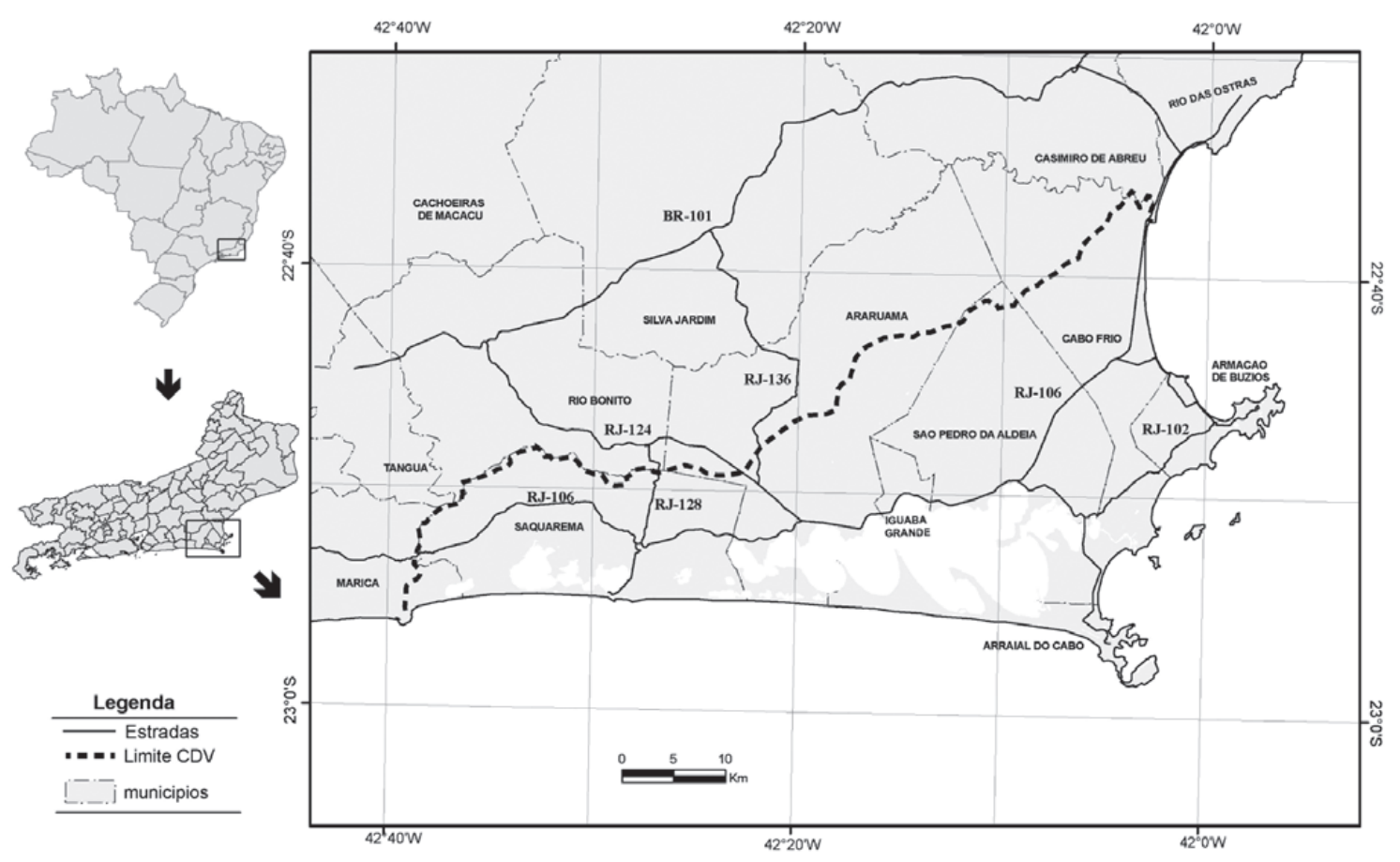

Figura 1 - Localização do Centro de Diversidade Vegetal de Cabo Frio - CDVCF. 
Arqueozóico e Proterozóico, posteriormente submetidos a movimentos tectônicos iniciados há aproximadamente 80 milhões de anos, com o soerguimento da borda do continente em todo o sudeste brasileiro, com rompimento e conseqüente rebaixamento dos blocos adjacentes. Nas colinas e maciços costeiros ocorrem duas unidades geológicas com diferentes idades: o Complexo Região dos Lagos, Paleoproterozóico, constituído por ortognaisses bandados/dobrados cinzentos, de composição tonálica a granítica, corresponde a um fragmento da placa Angolana, acrescida à borda leste da província Mantiqueira; enquanto que o Gnaisse Búzios, bandeado e de foliação horizontal, data do Proterozóico inferior (Penha 1999; Silva \& Cunha 2001).

As intrusões e extrusões de rochas Cenozóica alcalinas (Ilha do Cabo Frio e outras ocorrências menores), possuem idades entre $\sim 72$ e $50 \mathrm{Ma}$ (Penha 2000). Ainda durante o período Terciário ocorreram dois grupos alternados de processos erosivos (Ab'Saber 1992): erosão extensiva de encostas acompanhada por terraceamento lateral pela dissecamento vertical, e intensa pedogênese, acompanhada por relativa estabilidade da paisagem, com a formação dos tabuleiros costeiros (formação Barreiras), de ocorrência restrita na área. Flutuações climáticas iniciadas no início do Quaternário até o presente também influenciaram a paisagem atual, com expansão/retração de florestas úmidas e alterações do nível do mar (Ab'Saber 1977). Foram formados diversos ambientes de sedimentação associados a sistemas de deposição de origem continental e transicional marinho (Turcq et al. 1999).

Os Depósitos Colúvio-Aluvionares são constituídos por materiais variados, desde argila até blocos de rocha (matacões) provenientes do embasamento, e sedimentos arenosos e lamosos, eventualmente com cascalheiras, localizados em encostas baixas e ao longo de drenagens. Nos ambientes de sedimentação transicional/marinho encontram-se os Depósitos Pleistocênicos formados por Depósitos Praiais Marinhos e/ou Lagunares, relacionados ao último período transgressivo marinho. Entre Cabo Frio e Arraial do Cabo, a maior parte dos depósitos parcialmente recobertos por dunas holocênicas são de idade pleistocênica, preservados da última transgressão graças à presença das rochas cristalinas. Os Depósitos Fluvio-Lagunares estão geneticamente relacionados a episódios de progradação fluvial sobre ambiente transicional marinho/raso, estando bem representadas no curso dos rios São João e Una, com pequenas manchas situadas na parte continental interna da Lagoa de Araruama e em Búzios (Dantas 2000).

Os sistemas lagunares holocênicos ocorrem nas zonas baixas separando terraços arenosos pleistocênicos e holocênicos ou nos cursos inferiores de vales não preenchidos por sedimentos fluviais, sendo constituídos por sedimentos sílticos e/ou areno-argilosos ricos em matéria orgânica, podendo conter grande quantidade de conchas (Martin \& Suguio 1989). O sistema mais interno é ocupado pelas grandes lagunas que se situam entre as formações cristalinas e os depósitos pleistocênicos. O mais externo foi formado entre as barreiras pleistocênica e holocênica, constituído por lagoas pequenas e pouco profundas e com tendência ao ressecamento durante períodos de estiagem. Os Depósitos Praiais Marinhos holocênicos são constituídos por areias quartzosas esbranquiçadas, finas a médias, apresentando estratificação paralela com suave mergulho em direção ao mar. O pacote eólico apresenta-se na forma de depósitos próximos da linha de costa, e de dunas transgressivas, mais interiorizadas (Fernandez 2003).

O processo de formação dos cordões litorâneos e lagoas da região pode ser resumido em quatro fases (Fernandez 2003), com um máximo transgressivo anterior a 123.000 anos A.P. formando paleolagoas, seguido pelo recuo gradual do nível do até o máximo regressivo (18.000 anos A.P.), com a formação de tômbolos ligando o cordão pleistocênico aos morros costeiros e de depósitos lagunares entre o cordão e o cristalino. Ocorreu uma nova elevação do nível do mar até 5100 anos A.P., 
iniciando-se posteriormente uma nova deposição lacustre, com a formação dos cordões holocênicos e início da sedimentação lagunar, recuo da linha de costa e a construção das dunas frontais.

O mapeamento bioclimático do estado (Golfari \& Moosmayer 1980) aponta a peculiaridade climática e o elevado déficit hídrico da região, com forte influência sobre a vegetação florestal. A umidade relativa do ar média situa-se em torno de $83 \%$, com precipitação média anual variando de $1500 \mathrm{~mm}$, nas escarpas da serra e nas áreas mais baixas no seu limite Oeste (Am/w), a $800 \mathrm{~mm}$ ou menos, na porção entre Arraial do Cabo e Búzios, de clima semi-árido quente (Bsh) pela classificação de Köppen (Barbiére 1984). Já a temperatura varia de $9^{\circ}$ a $35^{\circ} \mathrm{C}$, com a média anual igual a $18^{\circ}-23^{\circ} \mathrm{C}$ (Bernardes 1952; Dantas et al. 2001; FIDERJ 1978). Ocorre uma estação seca curta a prolongada no inverno, amenizada em parte pelas frentes frias ocasionais e nas encostas, pela altitude, com déficit hídrico variando de nulo a mais de $300 \mathrm{~mm} / \mathrm{ano}$ (Freitas et al. 2005) (Fig. 2). Predominam ventos do quadrante NE, com a freqüência no verão superando $50 \%$, favorecidos pelo fortalecimento da Alta Pressão do Atlântico Sul, enquanto os ventos S e SO são mais frequientes no outono e inverno, associados às frentes frias (Barbiére 1985).

O clima peculiar da região deve-se a uma combinação de diversos fatores. A precipitação diminui gradualmente com o afastamento do topo da Serra do Mar em direção ao litoral e no sentido oeste-leste, devido ao menor controle orográfico. O efeito provocado pela ressurgência é condicionado pela brusca inflexão que a linha de costa sofre na altura do Cabo Frio, pela batimetria da plataforma continental e pelos constantes ventos $\mathrm{NE}$, deslocando a massa oceânica superficial aquecida e favorecendo a migração vertical de águas frias de subsuperfície, inibindo a formação de cúmulus responsáveis por chuvas convectivas (Barbiére 1975; Turcq et al. 1999; Moreira-da-Silva 1973).

A interação entre os diversos processos climáticos, geológicos, geomorfológicos e

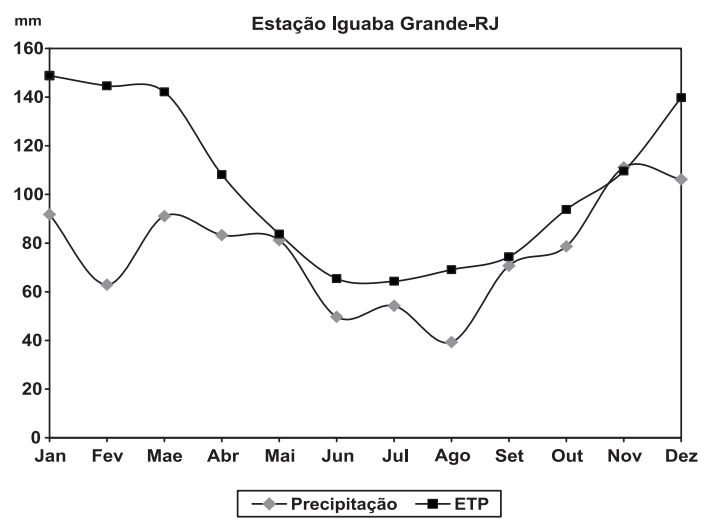

Figura 2 - Balanço hídrico com base em dados de 19701999, da Estação Meteorológica de Iguaba Grande (22 50 'S $, 42^{\circ} 10^{\prime} \mathrm{W}, 6 \mathrm{~m}$ alt.), localizada no centro do CDVCF, evidenciando o elevado déficit hídrico $(324 \mathrm{~mm})$, com a evapotranspiração potencial (ETP) (média anual de $1244 \mathrm{~mm}$ ) superando a precipitação (média anual de $920 \mathrm{~mm}$ ) em quase todos os meses do ano (Fonte: Freitas et al. 2005).

ecológicos ao longo do Pleistoceno resultou numa relativa diversidade de solos na região (Carvalho-Filho et al. 2000; Embrapa 1999). Os Argissolos, de maior ocorrência na região, são constituídos por material mineral, com horizonte B textural com argila de atividade baixa imediatamente abaixo do horizonte $\mathrm{A}$, baixos teores de $\mathrm{Fe}_{2} \mathrm{O}_{3}$, com predomínio de caulinita na fração argila. São em geral profundos e bem drenados, relacionados a terrenos cristalinos e sedimentos terciários, com teores variáveis de nutrientes. Incluem Argissolos Amarelo e Vermelho-Amarelo distróficos, distribuídos na maior parte da região, e eutróficos, ocupando as planícies e morros costeiros a leste. Os Latossolos são solos bem drenados de acidez elevada, com baixa capacidade de troca de cátions (CTC) e uma baixa reserva mineralógica, devido à intensa intemperização dos minerais primários. Ocupam colinas e parte das encostas da Serra do Mato Grosso, a oeste.

Os Planossolos são solos minerais, geralmente hidromórficos, com seqüência de horizontes A-Bt-C, caracterizados por mudança textural abrupta, horizonte B com alta densidade, com a ocorrência de cores de redução evidenciando condição de drenagem imperfeita, recobrindo 
áreas planas interiores. Gleissolos são solos minerais hidromórficos com horizonte glei superficial, pouco a medianamente profundos, mal ou muito mal drenados, periodicamente ou permanentemente inundados, horizonte A com acumulação de matéria orgânica e coloração escura, e sequiência de horizontes $\mathrm{A}$ e $\mathrm{Cg}$, com cores cinzentas, podendo ocorrer acúmulo de sais na superfície. São solos moderado a fortemente ácidos, com teores altos ou médios de Al trocável, distróficos ou eutróficos, ocorrendo em depressões inundadas entre cordões, várzeas e lagoas rasas perenes ou temporárias.

Espodossolos são solos com horizonte B podzol ou espódico subsuperficial, geralmente constituído de matéria orgânica, $\mathrm{Al}$ e Fe, com profundidade variável, imperfeitamente a mal drenado, textura arenosa, acumulação de húmus, ácido e de baixa fertilidade. O Espodossolo Cárbico possui acúmulo de carbono orgânico e Al no horizonte Bh, enquanto que o Ferrocárbico Hidromórfico Arênico possui maior acúmulo de $\mathrm{Fe}$, permanecendo saturado em um ou mais horizontes, e com alto teor de matéria orgânica (20-30\%). Recobrem terrenos mais baixos de restinga sujeitos a inundação.

Cambissolos são pouco evoluídos, com horizonte B incipiente ou câmbico, rasos a pouco profundos, moderadamente a bem drenados, distróficos e eutróficos, estes situados principalmente na Illha de Cabo Frio e nos morros costeiros entre Arraial do Cabo e Búzios. Neossolos são constituídos por material mineral pouco espesso, com ausência de horizonte B. Neossolos Quartzarênicos são solos com profundidade variável, excessivamente arenoso, ácido, álico ou distrófico, bem drenado, com alta lixiviação e baixa retenção de umidade, constituindo dunas e outras áreas arenosas. Os Neossolos Flúvicos são desenvolvidos a partir de depósitos aluviais recentes, apresentando estratificação de camadas e seqüência de horizontes do tipo A-C, eventualmente com evidências de gleização em subsuperfície. Ocorrem nos médios cursos dos rios, em geral associados aos Gleissolos. Já os Neossolos
Regolíticos apresentam um horizonte $\mathrm{A}$ assentado diretamente sobre o regolito, com horizonte $\mathrm{C}$ ou $\mathrm{B}$ incipiente pouco espesso, elevados teores de minerais primários, cascalhos e calhaus de rocha semi-intemperizada, geralmente associados aos Cambissolos, ocupando encostas íngremes e topos de colinas.

Organossolos são solos com alto teor de matéria orgânica (>0,2 kg/kg de solo), constituindo áreas de turfa relacionadas aos esporões internos da lagoa de Araruama e várzeas do rio São João, sujeitas à inundação. Finalmente, os solos indiscriminados de mangue são pouco desenvolvidos, sem diferenciação de horizontes, mal drenados, com baixa oxigenação e altos teores de sais e de compostos de enxofre, desenvolvidos a partir de sedimentos fluviomarinhos recentes, próximo à desembocadura do rio São João, com influência das marés.

\section{Mapeamento e classificação da cobertura vegetal}

Considerando o tamanho da área e a escala final de mapeamento, a disponibilidade de dados espaciais temáticos e o objetivo do trabalho, foi adotado um enfoque holístico, com o apoio de tecnologias de sensoriamento remoto e de sistemas de informações geográficas SIG (Zonneveld 1995). A definição do sistema de classificação fisionômico-estrutural adotado levou em conta os sistemas propostos para as regiões tropicais, os mapeamentos realizados no estado do Rio de Janeiro e a escala do mapa. O limite entre as florestas ombrófila e estacional foi determinado de acordo com a análise integrada de dados climáticos, relevo, solos e florísticos, além de observações de campo. Estas foram separadas também conforme o estágio de regeneração (inicial-médio e avançado). A classificação do uso do solo refere-se basicamente à relação entre o tipo de cobertura e os usos associados (IBGE 1999).

Foram reunidos e armazenados através do software ArcGIS 9.2, mapas digitais temáticos de geologia, geomorfologia, solos, precipitação e bioclimático (Dantas et al. 
2000; EMBRAPA 2003; Golfari \& Moosmayer 1980). Foram sobrepostos inicialmente os três primeiros, resultando na compartimentação regional em unidades físicas de paisagem refletindo a interação entre estes fatores. Foram armazenados ainda, além do mapa de vegetação do Projeto Radambrasil (1983), os mapas produzidos pelo Projeto de Conservação e Utilização Sustentável da Diversidade Biológica Brasileira - PROBIO e por Andrade (2006), conforme metodologias descritas a seguir.

O PROBIO mapeou na escala 1:250.000 a cobertura e uso do solo e os remanescentes da cobertura vegetal com base em cenas Landsat ETM de 2005, utilizando os programas Spring, PCI Orthoengine e eCognition. Foi realizada uma classificação supervisionada, segundo uma abordagem top-down, em dois níveis de segmentação: o primeiro, restrito às bandas do infravermelho próximo e médio, objetivando a identificação de áreas de sombra e corpos d'água; e o segundo, incluindo todas as bandas espectrais, exceto a do Azul, embasando o detalhamento das demais classes através de uma estrutura hierárquica, garantindo a herança entre os diferentes níveis. As classes de um mesmo nível foram diferenciadas por modelagem fuzzy de diferentes descritores, considerando principalmente valores espectrais, como média e desvio padrão das bandas, brilho e razões entre bandas. Estes modelos separaram grandes grupos, segundo a densidade da cobertura vegetal e a resposta espectral, respondendo pela primeira divisão entre coberturas naturais e os diferentes tipos de uso. Finalmente, foram utilizados descritores topológicos, de forma e temáticos (geomorfologia, solos), na identificação das diferentes fisionomias (Cruz et al. 2007).

No mapa de Andrade (2006), realizado com o apoio dos programas Spring e IDRISI, foram utilizadas todas as bandas (exceto a 6) de imagem Landsat 7 ETM de 1999 (período seco). Foi realizada uma classificação com segmentação por crescimento de regiões, com os limiares de segmentação modificados no detalhamento da vegetação na região mais seca do CDV (Andrade et al. 2005). Para realçar a separação entre as classes de vegetação úmida e seca, foi gerado um modelo linear de mistura, acompanhado de uma análise de componentes principais, que reduziu os dados espectrais para 3 bandas: respectivamente as "imagens-fração" solo, vegetação e sombra, e os três primeiros componentes principais.

Os três mapas de vegetação foram sobrepostos a uma imagem Landsat TM de 2007, identificando-se os polígonos com eventuais discrepâncias de classificação, redelimitados e reclassificados através de interpretação visual e sobrepostos ao mapa climáticos e de unidades de paisagem, verificando-se a existência de correlação espacial entre os tipos de vegetação e o ambiente físico. O cruzamento resultou num mapa preliminar de cobertura vegetal e de uso do solo, utilizado também para refinar o delineamento dos limites do CDVCF (Araujo 1997).

A verificação de campo, com apoio de GPS, contribuiu para a caracterização dos diferentes tipos fisionômicos e os limites entre as classes. Finalmente, foi feita a reinterpretação da imagem, com a delimitação final dos polígonos referentes às diferentes classes de cobertura.

\section{Resultados}

O mapa de vegetação potencial (Fig. 3) representa a interação entre cobertura vegetal e o ambiente físico da região, sem a influência antrópica. Mostra a ocorrência da Floresta Ombrófila Densa nos terrenos pré-cambrianos e pleistocênicos, com Latossolos, Argissolos, Cambissolos e Neossolos flúvicos, predominantemente distróficos, na porção central e oeste da região. A Floresta Estacional ocorre do centro para o leste, em áreas com precipitação média inferior a $1000 \mathrm{~mm}$ anuais, sobre o mesmo tipo de terreno, além dos tabuleiros terciários e morros alcalinos, com Argissolos, Cambissolos, Neossolos Regolíticos e Planossolos, geralmente eutróficos. As Formações Pioneiras ocupam as planícies arenosas de origem marinha, incluindo terraços, 


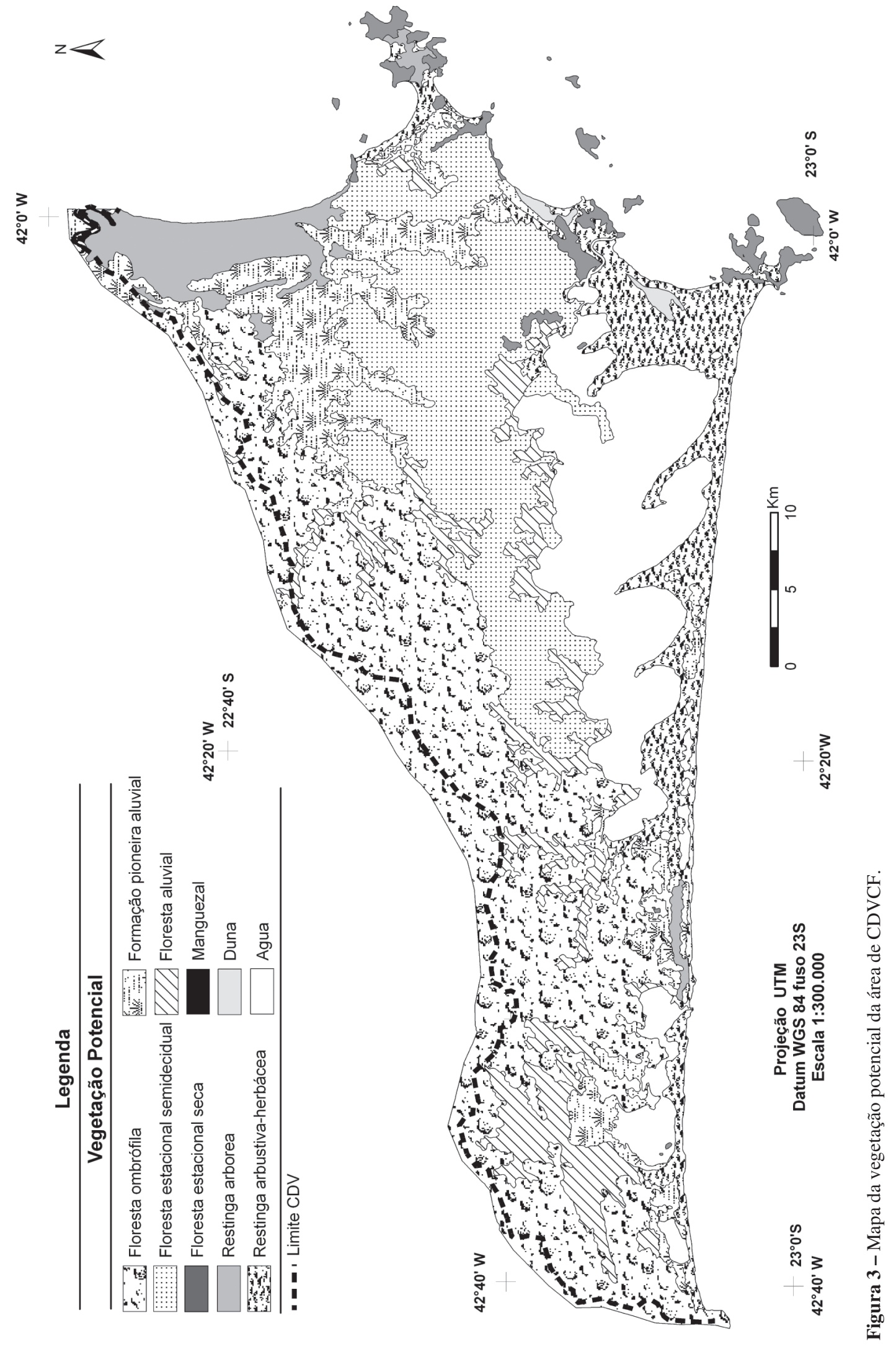


praias e campos de dunas, com Espodossolos e Neossolos Quartzarênicos; aluvial, com depressões, várzeas e margens de lagunas cobertas por vegetação herbácea e em alguns casos por florestas, com Gleissolos, Neossolos Flúvicos e Organossolos, e fluvio-marinha, constituída por manguezais.

O mapa de vegetação e uso do solo (Fig. 4) mostra a cobertura vegetal atual do CDVCF, com a área coberta por cada classe de mapeamento e a respectiva porcentagem em relação à área total do CDVCF apresentada na Tabela 1. A fisionomia de cada classe, sua relação com o ambiente físico e as espécies dominantes ou características são descritas a seguir.

\section{Floresta Ombrófila Densa}

A floresta ombrófila densa é uma vegetação com predominância de espécies arbóreas perenes, sem proteção nas gemas foliares, geralmente formando um dossel espesso e estratificado dominando por espécies macrofanerófitas, que atingem $20-35 \mathrm{~m}$, podendo ocorrer indivíduos emergentes, abundância de pteridófitas, epífitas e lianas, e presença de liquens nos troncos (Hueck 1972; Ururahy et al. 1983). O porte, a rapidez do desenvolvimento e a riqueza de espécies estão relacionados com a ocorrência de um período vegetativo contínuo com alta umidade e calor, dando a origem a adaptações para aproveitar a luz, como folhas largas, arquitetura das copas e a presença de lianas e epífitas (Guariguata \& Kattan 2002).

As formações aluvial (depressões e terraços com solos aluviais), terras baixas (até $100 \mathrm{~m}$ ) e submontana (> $100 \mathrm{~m})$, recobriam a porção central e oeste do CDVCF. Estes limites altitudinais propostos podem ser referendados ou alterados através de levantamentos florísticos e estruturais locais (Bohrer 1998; Moreno et al. 2003; OliveiraFilho et al. 2005). As áreas anteriormente ocupadas pelas formações aluvial e terras baixas foram as mais afetadas pelo processo de ocupação da região, concentrado nas áreas mais planas e de menor altitude, que facilitam o uso agrícola e pecuário. Restam apenas fragmentos de pequeno porte de florestas secundárias, com predominância de espécies pioneiras e secundárias iniciais (estágio inicial a médio de regeneração). A formação submontana, também afetada pela exploração madeireira, culturas do café, laranja, banana e pela pecuária, apresenta áreas de floresta secundária e outras em estágio avançado de regeneração. A predominância de solos distróficos e os processos erosivos, aliados à dificuldade de acesso e mecanização, e mais recentemente, de um maior rigor na fiscalização, tornaram possível a regeneração natural, com a restauração de parte das características da floresta original nas áreas de maior declividade, nas Serras do Mato Grosso e Palmital.

Apesar da inexistência de estudos florísticos e fitossociológicos locais, os resultados de estudos realizados em áreas relativamente próximas com ambientes semelhantes (Borém \& Oliveira-Filho 2002; Guedes-Bruni et al. 2006; Lima et al. 2006; Pessoa \& Oliveira 2006), possibilitam uma visão aproximada da estrutura e composição florística da floresta densa, indicando diversidade (até 100-200 ou mais espécies arbóreas/ha) e área basal (20-50 $\left.\mathrm{m}^{2} / \mathrm{ha}\right)$ relativamente altas. Estes dados, aliados a observações de campo, indicam a predominância de espécies das famílias Leguminosae (Inga, Piptadenia, Parapiptadenia, Senna, Caesalpinea, Machaerium), Rubiaceae (Psychotria), Myrtaceae (Eugenia), Euphorbiaceae (Alchornea), Moraceae (Cecropia, Ficus), Melastomataceae (Miconia, Tibouchina), Meliaceae (Cedrella, Trichilia), Lauraceae (Ocotea), Lecythidaceae (Cariniana), Annonaceae (Xylopia) e Palmae (Attalea, Astrocaryum, Geonoma), entre outras.

\section{Floresta Estacional Semidecidual}

Vegetação sujeita a duas estações, chuvosa e seca, e condicionando a resposta dos elementos arbóreos dominantes, com adaptações 


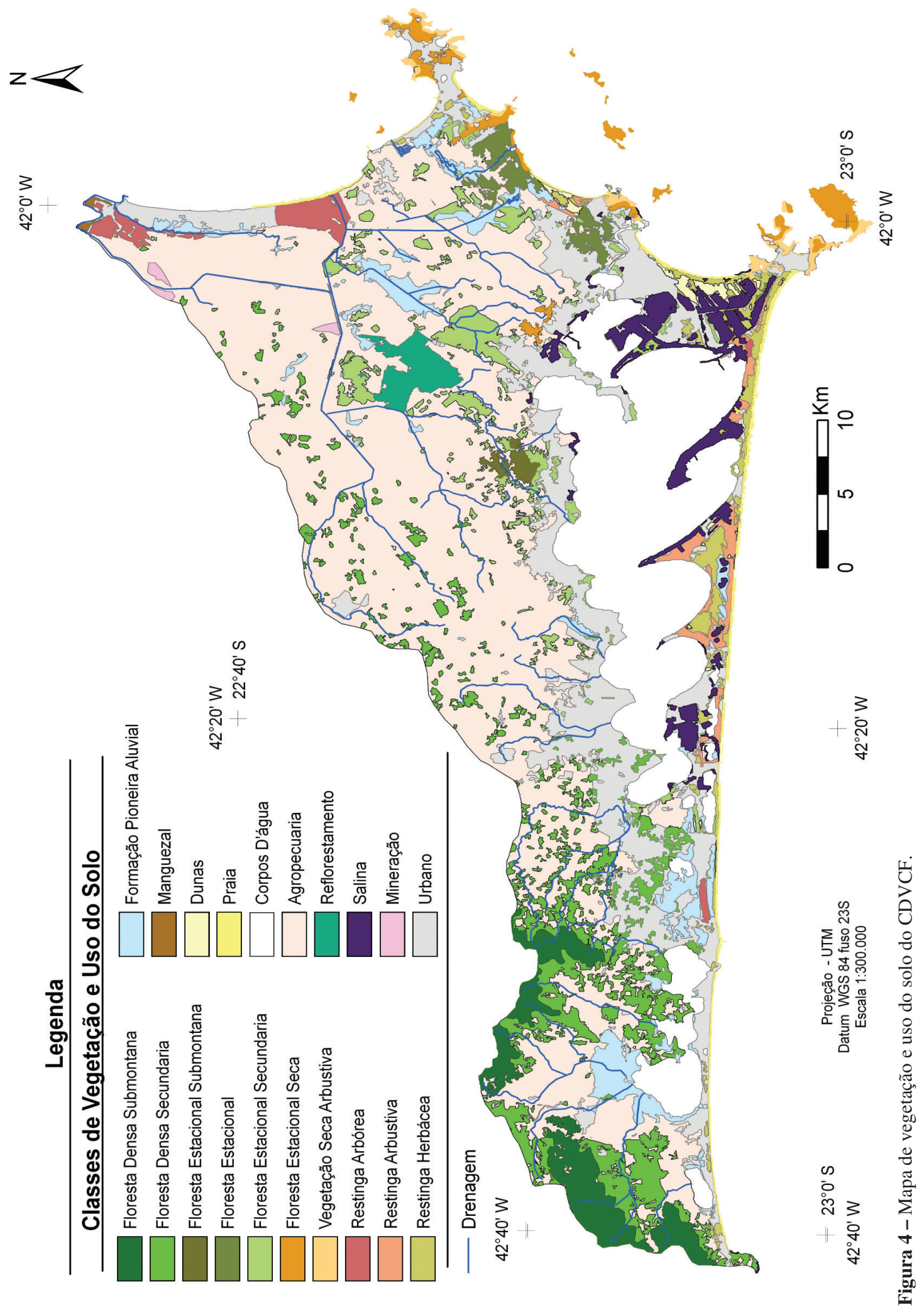


Tabela 1 - Área coberta pelas diferentes classes de cobertura vegetal e de uso do solo no Centro de Diversidade Vegetal de Cabo Frio.

\begin{tabular}{lrc}
\hline Classes de Cobertura Vegetal e de Uso do Solo & Área & $\mathbf{\%}$ \\
\hline I - Áreas Naturais & 37663,2 & 24,1 \\
1. Floresta Ombrófila Densa & 15644,8 & 10,0 \\
1.1. Floresta Densa Submontana & 4711,5 & 3,0 \\
1.2. Floresta Densa Secundária & 10933,3 & 7,0 \\
2. Floresta Estacional Semidecidual & 7350,2 & 4,7 \\
2.1 Floresta Estacional das terras baixas & 1570,9 & 1,0 \\
2.2. Floresta Estacional submontana & 448,0 & 0,3 \\
2.3. Floresta Estacional secundária & 5331,3 & 3,4 \\
3. Floresta Estacional Seca & 3034,0 & 1,9 \\
3.1. Floresta seca arbórea & 1722,4 & 1,1 \\
3.2. Vegetação seca arbustiva & 1311,6 & 0,8 \\
4. Formações Pioneiras & 11634,2 & 7,4 \\
4.1 Influência Marinha & 5536,4 & 3,5 \\
4.1.1. Restinga arbórea & 1596,0 & 1,0 \\
4.1.2. Restinga arbustiva & 1451,4 & 0,9 \\
4.1.3. Restinga herbácea & 2489,0 & 1,6 \\
4.2. Influência Aluvial & 6004,5 & 3,8 \\
4.3. Influência Fluvio-Marinha & 93,3 & 0,1 \\
II - Áreas Antrópicas & 90668,9 & 58,0 \\
1. Área Urbana & 20446,7 & 13,1 \\
2. Agropecuária & 64561,5 & 41,3 \\
3. Reflorestamento & 1532,7 & 1,0 \\
4. Mineração & 247,6 & 0,2 \\
5. Salina & 3879,3 & 2,5 \\
III - Áreas sem Vegetação & 27921,9 & 17,9 \\
1. Duna & 568,0 & 0,4 \\
2. Praia & 1577,7 & 1,0 \\
3. Corpo d'água & 25776,3 & 16,5 \\
\hline Total & $\mathbf{1 5 6 2 5 2 , 9}$ & $\mathbf{1 0 0 , 0}$ \\
\hline & & \\
\hline
\end{tabular}

morfológicas e fisiológicas à deficiência hídrica, com decidualidade de $20-50 \%$ da totalidade dos indivíduos arbóreos do dossel durante a estação seca (Veloso et al. 1991). Recobre os tabuleiros costeiros Terciários e terrenos pré-cambrianos entre o rio São João e as margens da Lagoa de Araruama. A floresta estacional semidecidual apresenta um grande número de espécies arbóreas em comum com a floresta ombrófila, acompanhadas de uma porcentagem menor de espécies exclusivas (Oliveira-Filho et al. 2005), sendo a sua flora arbórea composta por uma fração das espécies da floresta ombrófila, adaptadas a um maior estresse hídrico (Martins 1993). A diferenciação é maior quanto maior o estresse relacionado com os fatores do ambiente físico, como drenagem, fertilidade dos solos e influência marítima (Scarano 2006).

Originalmente a floresta semidecidual abrangia as formações aluvial, terras baixas e 
submontana, hoje bastante alteradas pela ação antrópica relacionada com o uso agropecuário, exploração florestal e, mais recentemente, pela expansão da ocupação urbana, restando poucos fragmentos remanescentes, com destaque para as APAs do Pau-Brasil (formação terras baixas) e da Serra de Sapiatiba (formação submontana). Nestes predominam, além de espécies de ocorrência comum na floresta ombrófila, espécies mais adaptadas a ambientes mais secos, como Actinostemon communis (Müll. Arg.) Pax, Aspidosperma sp., Anadenanthera colubrina (Vell.) Brenan, Caesalpinea echinata Lam., C. ferrea Mart., Clusia fluminensis Planch \& Triana, Erythroxylum pulchrum St.-Hil., E. subrotundum St.-Hil, Guapira opposita (Vell.) Reitz, Inga maritima Mart., Joannesia princeps Vell., Margaritaria nobilis L.f., Machaerium incorruptile (Vell.) Fr. All., M. lanceolatum (Vell.) Macbr., M. oblongifolium Vog., Metrodorea brevifolia Engl., Myrciaria floribunda (H. West. ex Will). O. Berg, Myrocarpus fastigiatus Fr. All., Parapiptadenia pterosperma (Benth.) Brenan, Pachistroma ilicifolium (Nees) Müll. Arg., Pterocarpus rohrii Vahl., Pseudobombax gradiflorum (Cav.) A.
Robyns, Pseudopiptadenia contorta (DC.) Lew. \& Lima e Zanthoxylum rhoifolium St.Hil., entre outras (Dantas et al. 2008; Farág 1999; Sá 2006).

\section{Floresta Estacional Seca}

Nas serras e morros mais próximos do mar (e.g., Serra das Emerenças, Ilha de Cabo Frio), com precipitação média inferior a 900 mm anuais e solos Argissolos e Neossolos regolíticos eutróficos rasos, a vegetação apresenta uma fisionomia bastante heterogênea. Combina áreas de porte florestal, árvores de maior porte e dossel atingindo $12-18 \mathrm{~m}$, nas porções do relevo côncavo, mais protegidas dos ventos Leste e NE e com maior umidade devido à drenagem, com vegetação arbórea-arbustiva mais baixa, de aspecto xerófitico, com 6-8 m e podendo atingir até $10 \mathrm{~m}$, em áreas mais secas e expostas, com árvores de menor diâmetro e maior ocorrência de espécies deciduais, espinhosas e suculentas, sendo comum também a ocorrência de caules perfilhados (múltiplos) e microfilia (Fig.5).

As vertentes que recebem os ventos marinhos carregados de salsugem, especialmente voltadas para as faces norte-leste, apresentam vegetação de porte arbustivo-arbóreo, densa e

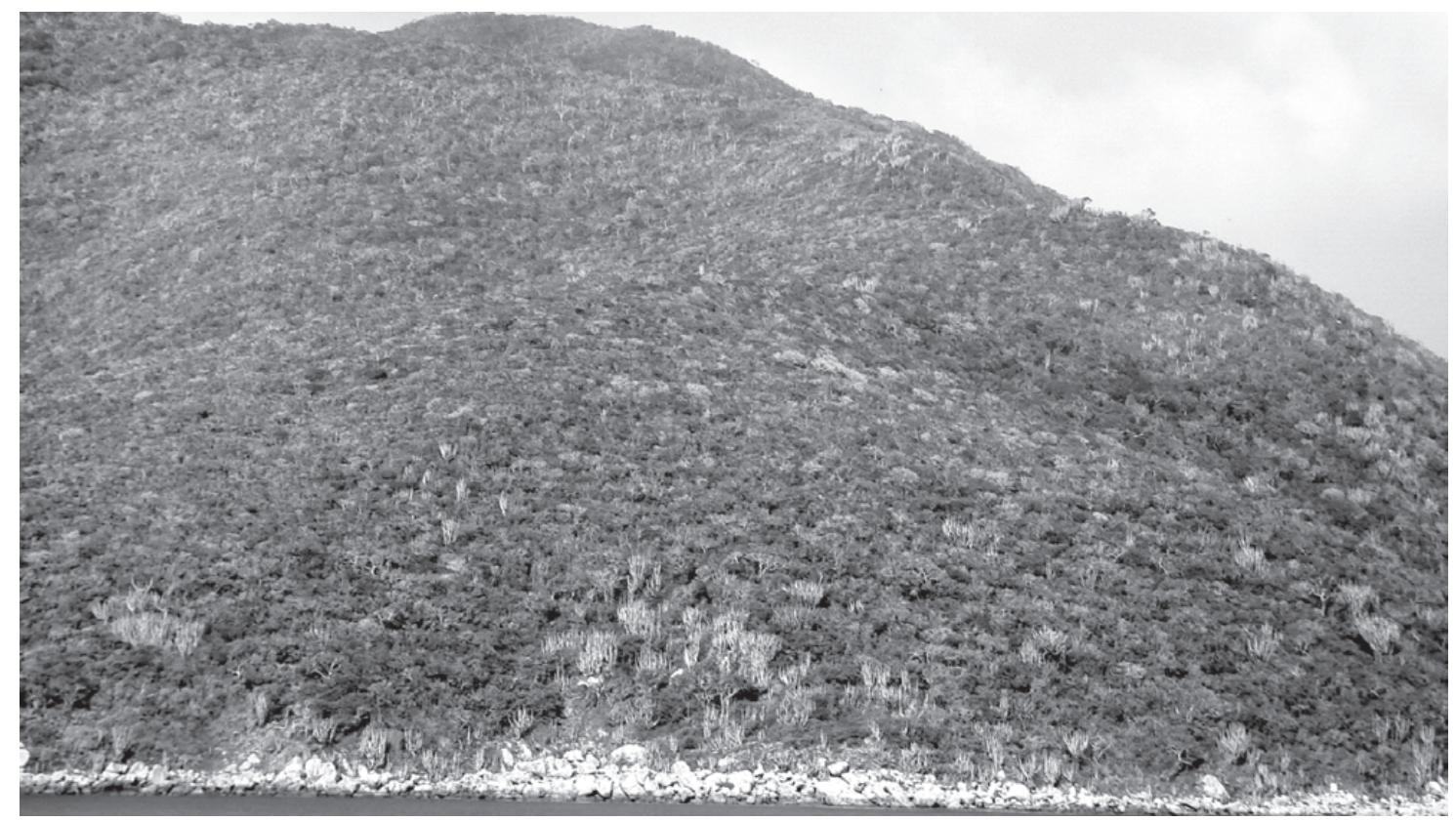

Figura 5 - Fotografia ilustrando o aspecto decidual e xerófito da vegetação da Ilha de Cabo Fio (classe Floresta Estacional Seca). 
emaranhada, com as cactáceas colunares Pilosocereus arrabidae (Lem.) Byles \& Rowley e P. ulei (K. Schum.) Byles \& Rowley destacando-se no dossel. Na formação, foi registrada a ocorrência das espécies arbóreas Aspidosperma parvifolium A. DC., A. ramiflorum Müll. Arg., Astronium graveolens Jacq., Caesalpinea echinata, Capparis flexuosa Vell, Ceiba erianthos (Cav.) K. Schum., Chrysophyllum lucentifolium Cronq., Erythroxylum pulchrum St.-Hil., Guapira opposita, Machaerium leucopterum Vog., M. pedicellatum Vog., Margaritaria nobilis, Maytenus obtusifolia Mart., Opuntia brasiliensis (Willd.) Haw., Pachistroma longifolium, Parapiptadenia pterosperma, Pterocarpus rhorii, Pseudobombax gradiflorum, Schinus terebinthifolius Raddi, Sideroxylon obtusifolium (Roem, \& Schult.) T.D. Penn., Tabebuia roseoalba (Rydl.) Sandw., Zanthoxylum tingoassuiba A. St.-Hil., Zollernia glabra (Spreng.) Yakovlev, e com porte arbustivo, Eugenia uniflora L., Rinorea laevigata (Sol. ex Ging.) Hekking, Jacquinia armilaris Jacq., Actinostemon communis (Müll. Arg.) Pax e Phylira brasiliensis Müll. Arg., entre outras (Dantas 2005; Sá 2006).

\section{Formação pioneira com influência marinha}

A vegetação de restinga recobre os terrenos sedimentares pleistocênicos e holocênicos de origem marinha, incluindo dunas, com Neossolos Quatzarênicos e depressões sujeitas a inundações periódicas ou permanentes, com Espodossolos ou Organossolos. A vegetação responde às pequenas variações de relevo, umidade, salinidade e exposição aos ventos, apresentando desde formações herbáceas características das comunidades localizadas próximas à praia e em depressões entre cordões arenosos, passando por formações arbustivas organizadas em ilhas de vegetação (moitas) de pequeno, médio e grande porte, até as formações de cobertura vegetal contínua de porte arbustivo a arbóreo. Esta variação fisionômica e a escala de mapeamento adotada no trabalho dificultam a utilização do sistema de classificação das comunidades vegetais de restinga, proposto por Araujo (1992). Deste modo, a classificação considerou basicamente a fisionomia, expressa pela densidade da cobertura vegetal e o porte das espécies dominantes (Menezes \& Araujo 2005).

As áreas de restinga encontram-se bastante impactadas pela ação antrópica ao longo das praias, acentuada nas últimas décadas, e pela expansão da ocupação para além dos núcleos urbanos, através de condomínios, loteamentos e invasões, com a valorização crescente das terras, ficando as áreas remanescentes geralmente concentradas em unidades de conservação (Rocha et al. 2007), grandes propriedades particulares e áreas militares. A degradação inclui também grandes áreas convertidas em salinas para a extração do sal, e até para destino final de rejeitos industriais (Araujo et al. 2004). Os impactos incluem a remoção total da vegetação, o plantio de espécies exóticas e a degradação parcial da vegetação em áreas de ocupação rarefeita, com o trânsito de veículos, pessoas e animais favorecendo a instalação de espécies invasoras. Extensas áreas de restinga são afetadas pela casuarina (Casuarina equisetifolia), espécie introduzida com a finalidade de fixar dunas e de paisagismo e que possui uma alta capacidade de colonização, ocupando especialmente áreas mais baixas ou onde ocorreu ação antrópica mais intensa, sendo comum nas margens de canais e salinas. Já a leucena (Leucaena leucocephala (Lam.) de Wit.), de introdução mais recente para fins de reflorestamento em áreas degradadas, vem se expandindo rapidamente em função de sua alta rusticidade, precocidade e adaptação a ambientes secos.

\section{Restinga arbórea}

Vegetação arbórea de porte florestal sobre terrenos arenosos secos, sazonalmente ou permanentemente inundados (Araujo 1992), com indivíduos de até $12 \mathrm{~m}$ ou mais de altura. Apresenta uma alta densidade de árvores e arbustos, além de trepadeiras, epífitas e bromélias terrestres, sendo comum a ocorrência de caules perfilhados (múltiplos), evidenciando a capacidade de rebrota de diversas espécies. A composição florística reflete a natureza transicional desta 
formação, evidenciada pela mistura de espécies típicas de restingas com espécies comuns às florestas ombrófila e estacional. No estrato arbóreo é comum a ocorrência das espécies Allophylus puberulus Radlk., Annona acutifora Mart., Aspidosperma pyricollum Müll. Arg., A. parvifolium, Astronium graveolens Jacq., Andira fraxinifolia Benth., A. legalis (Vell.) Toledo, Capparis flexuosa, Campomanesia guazumifolia (Cambess.) O. Berg., Chloroleucon tortum (Mart.) Pittier, Eriotheca pentaphyla (Vell.) A. Robyns, Erythroxylum pulchrum, E. ovalifolium Peyr., Eugenia uniflora, E. copacabanensis Kiaersk., Guapira opposita, G. nítida (Vell.) Reitz, Inga laurina Willd., I. maritima, I. subnuda Salzm ex Benth., Joannesia princeps, Lithraea brasiliensis Marchand, Maytenus obtusifolia, Myrcia racemosa (O. Berg) Kiaersk., Myrsine parvifolia A. DC., Ocotea diospyrifolia (Meisn.) Mez, Opuntia brasiliensis, Pachistroma ilicifolium, Parapiptadenia contorta, $P$. pterosperma, Pilosocereus arrabidae, Pouteria gradiflora (A. DC) Baehni, Protium heptaphyllum (Aubl.) Marchand, Pseudobombax grandiflorum, Psidium cattleayanum Sabine, Pterocarpus rohri, Schinus terebinthifolius, Swartzia acutifolia Vogel, S. apetala Raddi, Syderoxilum obtusifolium, Tabebuia cassinoides (Lam.) DC., Tapirira guianensis Aubl., Trichilia casaretti C. DC., Zollernia glabra (Fernandes \& Sá 2000; Fernandes 2005; Fonseca-Kruel \& Peixoto 2004; Lobão \& Kurtz 2000; Sá 1992). Os principais impactos causados a esta formação, além da sua remoção para expansão urbana, estão relacionados à ocorrência de queimadas e retirada de madeira.

\section{Restinga arbustiva}

Vegetação arbustiva sobre campo de dunas fixas, com Neossolos Quatzarênicos. A fisionomia é bastante heterogênea, incluindo áreas de vegetação aberta em moitas de diversos tamanhos intercaladas com áreas com vegetação esparsa ou solo nu; áreas com vegetação de médio porte (2-3 m) e cobertura nas cristas das dunas, geralmente moldada pelo vento, com depressões entre dunas com areia exposta ou recoberta por vegetação herbácea com predominância das halófitas, característica de locais úmidos com influência salina (Espodossolos); e extensas áreas de vegetação contínua e densa de maior porte (2-4 m), tanto nas cristas como nas vertentes e nos baixios entre dunas (Araujo 1992; Araujo et al. 2004). O espaço entre moitas pode ser ocupado por vegetação herbácea ou agrupamentos densos de Allagoptera arenaria (Gomes) Kuntze, com espécies lenhosas, cactáceas, bromélias e orquídeas no interior das moitas. Em diversas áreas de dunas baixas, a cobertura vegetal é dominada por A. arenaria, entre indivíduos isolados de Eugenia uniflora e Cereus fernambucensis Lem., entre outras.

Ocorrem ainda nesta formação as espécies Alibertia obtusa K. Schum., Byrsonima sericea DC., Campomanesia schchtendaliana (O. Berg.) Nied., Clusia fluminensis, $C$. hilariana Schltdl, Chloroleucon tortum, Cupania emarginata Cambess, Erythroxylum ovalifolium, Heteropterys chrisophyla (Lam.) Kunth, Jacquinia armillaris, Machaerium lanceolatum (Vell.) Macbr., Ouratea lushcnatiana (Tiegh.) K. Yamamoto, $O$. cuspidata (St.-Hil.) Engl., Pilosocereus arrabidae, Pouteria grandiflora, P. caimito (Ruiz \& Pav.) Radlk., Schinus terebinthifolius, Scutia arenicola (Casar.) Reissek, Senna australis (Vell.) Irwin \& Barneby, Tocoyena bullata (Vell.) Mart., Zollernia glabra (Araujo et al. 2004; Dantas 2005; Sá 2002).

\section{Restinga herbácea}

Essa formação herbácea inclui a vegetação halófila e psamófila reptante das praias, que se estendem por toda a área de dunas frontais junto à faixa de marés, das cristas e vertentes das dunas e depressões entre dunas (Araujo 1992; Araujo \& Henriques 1984; Araujo et al. 2004). A vegetação herbácea esparsa na região de dunas ativas, próxima à faixa de influência das marés, possui cobertura que varia desde rala até contínua e densa, dominada por gramíneas, com a presença ocasional de espécies lenhosas e suculentas formando moitas. Ocorrem também em depressões, entre o campo de dunas 
ativas e as dunas fixas, que podem ser inundadas pelo mar durante fortes ressacas, ou no período chuvoso, com a elevação do lençol freático. Geralmente a riqueza em espécies aumenta com o distanciamento em relação ao mar, com a cobertura ficando mais bem distribuída entre as espécies dominantes. Ocorrem as espécies Allagoptera arenaria, Althernanthera maritima (Mart.) St.-Hil, Blutaparon portulacoides (St.-Hil) Mears, Cereus fernambucensis, Chamaecyse thymifolia (L.) Millsp., Dalbergia ecastophyllum (L.) Taub., Ipomea pes-caprae (L.) Sweet, I. imperati (Vahl.) Griseb, Hybanthus calceolaria (L.) Oken, Hydrocotyle bonariensis Lam., Panicum racemosum (P. Beauv.) Spreng., Paspalum maritimum Trin, P. vaginatum Sw., Remirea maritma Aubl., Spartina ciliata Brongn., Sporolobus virginicus (L.) Kunth., Scaevola plumieri (L.) Vahl., Sesuvium portulacastrum (L.) L., Stenotaphrum secundatum (Walt.) Kuntze (Araujo et al. 2004; Cordeiro 2005; Dantas 2005; Sá 1996).

\section{Formação pioneira com influência aluvial (fluvial)}

Vegetação sobre terrenos sedimentares quaternários localizados ao longo das planícies aluviais e depressões, sujeitos a inundações periódicas ou permanentes, formando brejos e campos inundáveis, sobre Gleissolos e Organossolos. Possui fisionomia herbácea a arbustiva, com composição florística variável, de acordo com a intensidade e duração da inundação, o grau de oxigenação e salinidade, e a textura do solo. Inclui áreas de restinga inundável, localizadas nas margens dos espelhos d'água e depressões entre dunas, sobre Espodossolos ou Organossolos inundadas periodicamente pelas águas das chuvas e o afloramento do lençol freático, com cobertura vegetal em faixas, as quais devido à sua pequena extensão foram, em muitos casos, englobadas nas classes restinga arbustiva ou herbácea.

Apesar de sua ocorrência relativamente ampla na região, não foram encontrados estudos específicos sobre esta formação, embora existam dados florísticos englobando os ecossistemas aquáticos temporários de toda a planície costeira do estado (Bove et al. 2003) e estudos locais sobre restingas, incluindo dados de depressões entre dunas e margens de lagoas. Predominam gêneros e espécies adaptadas ao ambiente hidrófilo das famílias Cyperaceae (Cyperus, Eleocharis, Hypoginum, Lagenocarpus, Scleria), Gramineae (Echinochloa, Panicum, Paspalum), e de pteridófitas (Acrostichum), além de Blechnum serrulatum Rich., Aechmea spp., Canna glauca L., Hydrocotile, Nymphaea, Typha dominguensis Pers., Xyris, e arbustivas como Bactris setosa Mart., Chrysobalanus icaco L., Dalbergia ecastophyllum (L.) Taub., Gaylussacia brasiliensis (Spr.) Meissn., Humiria balsamifera Aubl., Marcetia taxifolia (St.-Hil) DC., Tibouchina litoralis Ule (Araujo et al. 2004; Bove et al. 2003; Sá 1992; 1996).

Os ambientes inundáveis são áreas com alta produtividade biológica e servem de abrigo para um grande número de espécies de aves aquáticas residentes ou migratórias, e de diversas espécies de vertebrados e invertebrados. Geralmente encontram-se bastante alterados, devido ao longo processo de ação antrópica, especialmente com as obras de aterros, drenagem, retificação e canalização de rios, e conversão de áreas para agricultura e urbanização. Estes fatores, aliado ao padrão semelhante às áreas de pastagens, torna difícil a sua delimitação em imagens e fotografias aéreas.

\section{Formação pioneira com influência fluvio-marinha}

Vegetação litorânea sobre áreas de transição entre os ambientes terrestre e aquático, característica de regiões tropicais submetidas a regime de marés, constituída de espécies vegetais típicas adaptadas a flutuações de salinidade e sedimentos predominantemente lodosos, com baixos teores de oxigênio. Ocorre em faixas estreitas ao longo do baixo curso do rio São João, sendo caracterizada pelas espécies arbóreas Avicennia schaueriana Stapf \& Leechm. ex Moldenke e Laguncularia racemosa (L.) C.F. Gaertn. 


\section{Áreas antrópicas}

As áreas antrópicas cobrem 58,1\% da área do CDVCF, na maior parte constituída por pastagens, seguidas por plantios florestais e agricultura. O desmatamento extensivo está relacionado ao processo histórico de ocupação da área, com exploração de madeira, especialmente do pau-brasil (Caesalpinea echinata), plantios de cana, café e laranja, pecuária e cultivos anuais. A população rural encontra-se estabelecida em pequenos núcleos rurais, e pequenas, médias e grandes fazendas. As pequenas propriedades baseiam-se na produção agrícola e olerícola, e a pecuária de pequeno porte, sendo comum a ocorrência de policultivos. De modo geral, como resultado de ações que modificam o perfil do terreno, removem ou danificam seriamente a vegetação natural, é comum em toda a área rural e periferia urbana a presença de espécies ruderais, cosmopolitas e exóticas.

\section{Agropecuária}

As áreas de cultura agrícolas anuais e perenes e de pastagens $(41,3 \%)$ foram reunidas na classe de cobertura Agropecuária em função da dificuldade de separação espectral nas imagens de satélite. Os levantamentos prévios e os trabalhos de campo comprovam a predominância de pastagens para pecuária de corte em grandes propriedades, nas áreas de relevo colinoso suave e em terrenos aluviais e hidromórficos drenados, boa parte composta por solos eutróficos. Ocorrem culturas anuais em pequena escala, com a presença de algumas áreas com culturas perenes como coco, banana e citros, a oeste e norte do CDVCF.

\section{Reflorestamento}

O reflorestamento com Eucalyptus spp. está concentrado em uma extensa área (1532 ha) ao longo da rodovia RJ-106, em S. Pedro da Aldeia, e em área menores não mapeáveis.

\section{Salinas e mineração}

Apesar da decadência da indústria do sal, a região apresenta ainda uma área considerável coberta por salinas, nas margens leste e sul da
Lagoa de Araruama, formando um traço marcante da paisagem cultural da região. $\mathrm{O}$ encerramento de atividades de diversas empresas, com o conseqüente abandono, vem disponibilizando algumas áreas para ocupação urbana. Foram mapeadas ainda algumas áreas de mineração, com extração de areia, brita e areola.

\section{Áreas urbanas}

As áreas urbanas recobrem uma área considerável $(13,1 \%)$, com maior concentração nas sedes municipais, no entorno da Lagoa de Araruama, ao longo das rodovias RJ 106 e RJ 140 e nas áreas costeiras. A comparação com mapeamentos anteriores comprova a rápida expansão da urbanização, especialmente sobre os terrenos de restinga (Bohrer 2003b; Rocha et al. 2007), além de áreas de planícies e morros costeiros, constituindo-se atualmente no principal fator de degradação da vegetação natural do CDVCF.

\section{Áreas sem vegetação}

Incluem-se nesta classe as áreas de dunas móveis, com cobertura vegetal escassa ou ausente, as praias e corpos d'água (rios, lagoas e pequenas represas ou açudes), que correspondem a $17,9 \%$ da área do CDVCF.

\section{Discussão}

A região do CDVCF apresenta um forte gradiente de precipitação em uma área relativamente restrita, o qual combinado com variações locais de fatores como o relevo, solos, proximidade do mar e incidência de ventos, resulta numa alta heterogeneidade ambiental, relacionada especialmente à umidade, evapotranspiração, $\mathrm{pH}$ e níveis de nutrientes disponíveis para as plantas. A variação gradual da fisionomia, desde as florestas densas e perenes das encostas e planícies a oeste e noroeste, até as fisionomias arbóreo-arbustivas de porte médio e baixo, que cobrem os morros e colinas litorâneas entre Arraial do Cabo e Búzios, passando por florestas estacionais, campos aluviais e restingas herbáceas a arbóreas, reflete este padrão. 
Esta variação gradual da vegetação, combinada com o alto grau de impacto antrópico, expresso pela pequena extensão de áreas com cobertura florestal, o estágio sucessional dos poucos fragmentos remanescentes e a escassez de dados florísticos e estruturais, dificulta bastante a definição dos limites entre as formações florestais. Deste modo, os limites e a definição das classes de mapeamento adotados neste trabalho devem ser vistos como uma hipótese a ser testada através de novos levantamentos estruturais e florísticos, estudos ecológicos e mapeamentos, com a utilização de imagens multiespectrais ou fotografias aéreas ortorretificadas de alta resolução espacial (Dantas et al. 2009; Jamel 2004).

Análises realizadas com dados florísticos (presença de espécies arbóreas) e ambientais de diversas áreas da Região Sudeste apontam para uma maior similaridade da vegetação arbórea de Búzios (Araujo et al. 1998) com áreas de restinga arbórea e as florestas de tabuleiro ao norte do Estado, Espírito Santo e sul da Bahia, quando comparada com áreas de floresta densa do estado (Bohrer 1998; Oliveira-Filho \& Fontes 2000), caracterizando o que pode ser interpretado como um enclave na floresta pluvial (Hueck 1972), sugerindo uma cobertura vegetal única ligando estas áreas em passado recente (período Quaternário).

A caracterização da vegetação dos morros costeiros como disjunção fisionômica da caatinga nordestina, pelo Radambrasil, reflete, além de aspectos climáticos, estruturais e fisionômicos, a adoção da Teoria dos Refúgios (Ab’Saber 1977, 1992; Prance 1982), pela qual as flutuações climáticas ocorridas no Pleistoceno induziram a uma expansão das áreas de clima frio e seco, o que, aliado à diminuição do nível do mar, teria favorecido a dispersão de formas xerófitas ao longo do litoral. Com o retorno de climas mais quentes e úmidos, essas teriam sobrevivido em refúgios atuais. Análises florísticas em escala continental apontam para períodos de expansão e retração das florestas secas, incluindo a caatinga, em toda a América tropical, durante o Quaternário (Pennington et al. 2000, 2004).
Prado (2000) destaca a concentração na região do CDVCF de taxa indicadores da Região Biogeográfica das Florestas Estacionais da América do Sul, relacionada ao denominado Arco Pleistocênico que teria unido áreas atualmente separadas geograficamente (Prado \& Gibbs 1993), nas quais se incluem a caatinga e a formação decidual conhecida como matade-cipó, localizada no planalto oriental entre os estados da Bahia e Minas Gerais. Sá (2006) aponta para uma maior similaridade florística entre as florestas estacionais da região e diversas áreas do estado, em comparação com áreas de caatinga da Região Nordeste do país, refletindo provavelmente um padrão relacionado à proximidade geográfica entre as áreas (Oliveira-Filho et al. 2005). Novas análises a partir de dados florísticos, estruturais e ambientais, combinadas com estudos ecofisiológicos e paleoecológicos, poderão elucidar melhor esta questão.

A alta proporção de áreas antrópicas em toda a região, a predominância de florestas secundárias, e o alto grau de fragmentação das áreas de vegetação natural remanescentes, afetadas por aspectos como o tamanho, forma e grau de isolamento, relacionados com o efeito de borda, indicam a necessidade urgente de implantação efetiva dos planos de manejo das unidades de conservação estaduais (APAs do Pau Brasil, Massambaba e Sapíatiba) e municipais existentes, bem como da proteção de áreas adicionais, em ambientes de restinga e de florestas densas e estacionais. Aiminência de implantação de novos empreendimentos turísticos de grande porte em áreas que ainda apresentam vegetação natural em bom estado de conservação, protegidas pela legislação ambiental em vigor, é mais um fator de preocupação com a conservação das espécies e ecossistemas da região.

\section{Conclusão}

A utilização de diversas fontes de dados temáticos espaciais em combinação com a interpretação de imagens orbitais, auxiliadas pelas técnicas de geoprocessamento utilizadas, 
possibilitou o mapeamento e classificação da vegetação e uso do solo CDVCF de modo satisfatório e compatível com o tamanho da área e a escala adotada, e a disponibilidade de dados florísticos e estruturais. Este trabalho pode ser refinado através de novos mapeamentos com imagens de maior resolução espacial, em estreita associação com levantamentos de campo, de modo que as análises florísticas e estruturais pontuais possam, em combinação com um maior entendimento da relação entre a vegetação e o ambiente físico, servir como parâmetro de referência para o refinamento e delimitação mais acurada das classes de cobertura vegetal. A riqueza em espécies, singularidade fisionômica, variedade e complexidade de habitats e ainda, a ocorrência de espécies endêmicas, ameaçadas, medicinais e ornamentais, realçam a necessidade de medidas urgentes de preservação das áreas de vegetação natural remanescentes do CDVCF, de grande importância ambiental, científica e paisagística.

\section{Agradecimentos}

Os autores gostariam de expressar os seus agradecimentos aos Drs. Cyl Farney C. de Sá, Dorothy S. D. Araujo, Haroldo C. Lima e Miriam C. Pereira pelas discussões técnicas e apoio em trabalhos de campo, e à FAPERJ, pelo suporte financeiro.

\section{REFERÊNCIAS BibLIOGRÁFICAS}

Ab' Saber, A. N. 1992. A Serra do Japi, sua origem geomorfológica e a teoria dos refúgios. In: Morellato, L. P. C. (org.). História natural da Serra do Japí: ecologia e preservação de uma área florestal no sudeste do Brasil. Ed. UNICAMPFAPESP, Campinas. Pp. 12-23.

1977. Espaços ocupados pela expansão dos climas secos na América do Sul, por ocasião dos períodos glaciais quaternários. Paleoclimas 3:1-18.

Andrade, S. F. 2006. Classificação digital e índices de vegetação da região de Cabo Frio - RJ. Dissertação de mestrado. UFF, Niterói, 102p.
; Carvalho, C. N.; Francisco, C. \& Coe, H. H. 2005. Identificação da vegetação xerófila da região de Cabo FrioRJ, com auxílio de geoprocessamento. In: Anais do XI Simpósio Brasileiro de Geografia Física Aplicada. USP, São Paulo. Pp. 2516-2525.

Araujo, D. S. D. \& Henriques, R. B. P. 1984. Análise florística das restingas do Rio de Janeiro. In: Lacerda, L. D.; Araujo D. S. D.; Cerqueira, R. \& Turcq, B. (orgs.). Restingas: origem, estrutura, processos. CEUFF, Niterói. Pp.159-193.

1992. Vegetation types of sandy coastal plains of tropical Brazil: a first approximation. In: Seeliger, U. (ed.). Coastal plant communities of Latin America. Academic Press, San Diego. Pp. 337-347. 1997. The Cabo Frio region. In: Davis, S. D.; Heywood, V. H.; HerreraMacBryde, O.; Villa-Lobos, J. \& Hamilton, A. C. (eds.). Centres of plant diversity: a guide and strategy for their conservation. The Americas, WWF-IUCN, Oxford. Vol. 3. Pp. 373-375. 2000. Análise florística das restingas do estado do Rio de Janeiro. Tese de Doutorado. UFRJ, Rio de Janeiro.

; Bohrer, C. B. A.; Sá, C. F.; Mattos, E. A.; Neves, M. H. B.; Dantas, H. G. R.; Pereira, M. C. A. \& Paes, A. T. 2004. Definição de unidades de conservação e proposta de plano de manejo, Praia Grande, Arraial do Cabo, RJ. Relatório Técnico. Prefeitura Municipal de Arraial do Cabo/CIA Álcalis, Arraial do Cabo.

; Lima, H. C.; Farág, P. R.; Lobão, A. Q.; Sá, C. F. \& Kurtz, B. 1998. O centro de diversidade vegetal de Cabo Frio: levantamento preliminar da flora. In: IV Simpósio de Ecossistemas Brasileiros, Águas de Lindoia. Pub. ACIESP n ${ }^{\circ} 104$. São Paulo. 2: 165-170.

Austin, M. P. 2005. Vegetation and environment: discontinuities and continuities. In: van der Maarel, E. (ed.). Vegetation ecology. Blackwell, Oxford. Pp. 52-84. 
Azevedo, A. 1950. Regiões climato-botânicas do Brasil. Boletim Paulista de Geografia 6: 32-43.

Barbiéri, E. 1975. Ritmo climático e extração de sal em Cabo Frio. Revista Brasileira de Geografia 37: 23-109.

1984. Cabo Frio e Iguaba Grande: dois microclimas distintos a um curto intervalo espacial. In: Lacerda, L. D.; Araujo, D. S. D.; Cerqueira, R. \& Turcq, B. (eds.). Restingas: origem, estruturas, processos. CEUFF, Niterói. Pp. 3-13.

1985. Condições climáticas dominantes na porção oriental da lagoa de Araruama (RJ) e suas implicações na diversidade do teor de salinidade. Cadernos Ciências da Terra 59: 3-34.

Beard, J. S. 1946. Climax vegetation in tropical America. Ecology 25: 127-158.

1955. The classification of tropical America vegetation types. Ecology 36: 89-100.

1978. The physiognomic approach. In: Whittaker, R. H. (ed.). Classification of plant communities. $2^{\text {nd }}$ ed. Junk, The Hague. Pp. 35-64.

Bernardes, L. M. C. 1952. Tipos de clima do estado do Rio de Janeiro. Revista Brasileira de Geografia 14: 57-80.

Bidegain, P. S. P. \& Bizerril, C. R. S. F. 2002. Lagoa de Araruama - perfil ambiental do maior ecossistema lagunar hipersalino do mundo. SEMADS/GTZ 12. Rio de Janeiro.

Bohrer, C. B. A. 1998. Ecology and biogeography of an Atlantic montane forest in southeastern Brazil. Tese de Doutorado. University of Edinburgh, 234p.

2000. Vegetação, paisagem e o planejamento do uso da terra. GEOgraphia 4: $103-120$

. 2003a. Legenda do mapa do IQM Verde II. In: Índice de qualidade de municípios - verde. Fundação CIDE. 2 ${ }^{\underline{a}}$ ed. ampliada. Rio de Janeiro. Pp. 15-28. 2003b. Evolução da cobertura de florestas e de vegetação secundária do Estado do Rio de Janeiro - mapas IBGE/ DSG-1956/1975 e mapa CIDE-2001. In:
Índice de qualidade de municípios - verde. Fundação CIDE. 2a ed. amp. Rio de Janeiro. Pp. 71-97.

Borém, R. A. T. \& Oliveira-Filho, A. T. 2002. Fitossociologia do estrato arbóreo em uma topossequência alterada de Mata Atlântica, no município de Silva JardimRJ, Brasil. Revista Árvore 26: 727-742.

Bove, C. P.; Gil, A. S. B.; Moreira, C. B. \& Anjos, R. F. B. 2003. Hidrófitas fanerogâmicas de ecossistemas aquáticos temporários da planície costeira do estado do Rio de Janeiro, Brasil. Acta Botanica Brasilica 17: 119-135.

Carvalho-Filho, A.; Lumbreras, J. F. \& Antos, R. D. 2000. Os solos do estado do Rio de Janeiro. CPRM-EMBRAPA Solos. Brasília.

CIDE. 2000. Índice de qualidade dos municípios - verde. Fund. CIDE, Rio de Janeiro.

Cordeiro, S. Z. 2005. Composição e distribuição da vegetação herbácea em três áreas com fisionomia distintas na Praia do Peró, Cabo Frio, RJ, Brasil. Acta Botanica Brasilica 19: 679-693.

Cruz, C. M.; Vicens, R. S.; Seabra, V. S.; Reis, R. B.; Faber, O. A.; Richter, M.; Arnaut, P. K. \& Araujo, M. H. S. 2007. Classificação orientada a objetos no mapeamento dos remanescentes da cobertura vegetal do bioma Mata Atlântica, na escala 1:250.000. In: Anais do XIII Simpósio Brasileiro de Sensoriamento Remoto. INPE, Florianópolis. Pp. 5691-5698.

Dantas, H. G. 2005. Paisagem e vegetação do município de Armação de Búzios, Rio de Janeiro. Dissertação de Mestrado. ENBT-IPJBRJ, Rio de Janeiro.

Dantas, H. G. R.; Lima, H. C. \& Bohrer, C. B. A. 2008. Mapeamento da vegetação e da paisagem do município de Armação dos Búzios, Rio de Janeiro, Brasil. Rodriguésia. 60(1): 25-38.

Dantas, M. 2000. Geomorfologia do estado do Rio de Janeiro. CPRM, Brasília.

Dantas, M. E.; Shinzato, E.; Medina, A. I. M.; Silva, C. R.; Pimentel, J.; Lumbreras, J. F. \& Calderano, S. B. 2001. Diagnóstico 
geoambiental do estado do Rio de Janeiro. CPRM, Brasília.

Ellenberg, H. \& Mueller-Dombois, D. 1967. Tentative physiognomic-ecological classification of plant formations of the earth. Bericht uber das Geobotanishe Institute. ETH, Stiftg. Rübel, Zurich 37: 21-55.

EMBRAPA. 1999. Sistema brasileiro de classificação de solos. SPF-EMBAPA, Brasília.

2003. Mapa de solos e vulnerabilidade das terras da Região dos Lagos, escala 1:100.000. EMBRAPA Solos, Rio de Janeiro.

Farág, P. R. C. 1999. Estrutura do estrato arbóreo de mata litorânea semicaducifolia sobre solo arenoso no Município de Búzios, RJ. Dissertação de Mestrado. MN/UFRJ. Rio de Janeiro, 86p.

Fernandes, D. S. 2005. Estrutura de uma floresta seca de restinga em Cabo Frio, RJ. Dissertação de Mestrado. ENBT/ IPJBRJ. Rio de Janeiro, 38p.

\& Sá, C. F. C. 2000. Estudo florístico preliminar das restingas remanescentes do município de Armação dos Búzios/RJ. In: Anais do V Simpósio de Ecossistemas Brasileiros. Vitória, ES. Vol. 3. Pp. 57-65.

Fernandez, G. B. 2003. Morfologia e dinâmica do sistema praia-duna frontal e antepraia em ambiente de alta energia: Praia da Massambaba, extremo leste do litoral do estado do Rio de Janeiro, Brasil. Tese de Doutorado. UFRJ, Rio de Janeiro, 140p.

FIDERJ. 1978. Indicadores climatológicos do estado do Rio de Janeiro. FIDERJ, Rio de Janeiro.

Fonseca-Kruel, V. S.; Araujo, D. S. D.; Sá, C. F. C. \& Peixoto, A. L. 2009. Quantitative ethnobotany of a resting a forest fragment in Rio de Janeiro, Brazil. Rodriguésia 60(1): 187-202.

Freitas, I. M.; Bohrer, C. B. A. \& Oliveira, J. L. F. 2005. O clima do município de Iguaba Grande (RJ): características, vegetação natural e agricultura. In: Anais do XI Simpósio Brasileiro de Geografia Física Aplicada. USP, São Paulo. Pp. 3384-3392.
Golfari, L. \& Moosmayer, H. 1980. Manual de reflorestamento do estado do Rio de Janeiro. BD-Rio, Rio de Janeiro.

Guariguata, M. R. \& Kattan, G. H. 2002. Ecologia y conservación de bosques neotropicales. Ediciones LUR, Cartago.

Guedes-Bruni, R. R.; Silva Neto, S. J.; Morim, M. P. \& Mantovani, W. 2006. Composição florística e estrutura de trecho de floresta ombrófila densa atlântica aluvial na Reserva Biológica de Poço das Antas, Silva Jardim, Rio de Janeiro, Brasil. Rodriguesia 57: 413-428.

Hueck, K. 1972. As florestas da América do Sul. Ed. UnB-Polígono, Brasília.

IBGE. 1993. Mapa de vegetação do Brasil. $2^{\mathrm{a}}$ ed. IBGE, Rio de Janeiro. 1999. Manual técnico de uso da terra. IBGE, Série Manuais Técnicos em Geociências № 7, Rio de Janeiro.

Jamel, C. E. G. 2004. Caracterização da vegetação da restinga de Jurubatiba com base em sensoriamento remoto e sistema de informação geográfico: estado atual e perspectivas. In: Rocha, C. F. D.; Esteves, F. A. \& Scarano, F. R. (orgs.). Pesquisas de longa duração na restinga de Jurubatiba: ecologia, história natural e conservação. RiMa, São Carlos. Pp. 25-42.

Kent, M. \& Coker, P. 1992. Vegetation description and analysis - A practical approach. John Willey \& Sons, Chichester.

Küchler, A. W. 1988a. Physiognomic and structural analysis of vegetation. In: Küchler, A. W \& Zonneveld, I. S. (eds.). Vegetation Mapping. Kluwer Academic, Dordrecht. Pp. 37-50. 1988b. The classification of vegetation. In: Küchler, A. W \& Zonneveld, I. S. (eds.). Vegetation Mapping. Kluwer Academic, Dordrecht. Pp. 67-81.

Lima, H. C. 2000. Leguminosas arbóreas da Mata Atlântica, Rio de Janeiro. Tese de Doutorado. UFRJ, Rio de Janeiro, 156p. ; Pessoa, S. V. A.; Guedes-Bruni, R. R.; Moraes, L. F. D.; Granzotto, S. V.; Iwamoto, S. \& Di Ciero, J. 2006. Caracterização fisionômico-florística e mapeamento da 
vegetação da Reserva Biológica de Poço das Antas, Silva Jardim, Rio de Janeiro, Brasil. Rodriguésia 57: 369-389.

Lobão, A. Q. \& Kurtz, B. C. 2000. Fitossociologia de um trecho de mata de restinga na praia Gorda, município de Armação dos Búzios, RJ.In: Anais do V Simpósio de Ecossistemas Brasileiros, Vitória, ES. Vol. 3. Pp. 66-75.

Martin, L. \& Suguio, K. 1989. Excursion route along Brazilian coast between Santos and Campos. International Symposium on Global Changes in South America during the Quaternary. Special Publication № 2. São Paulo.

Martins, F. R. 1993. Estrutura de uma floresta mesófila. $2^{\mathrm{a}}$ ed. Ed. UNICAMP, Campinas.

Menezes, L. F. T. \& Araujo, D. S. D. 2005. Formações vegetais da restinga da Marambaia, Rio de Janeiro. In: Menezes, L. F. T.; Peixoto, A. L. \& Araujo, D. S. D. (eds.). História natural da Marambaia, EDUR, Seropédica. Pp. 67-132.

Moreira-da-Silva, P. M. 1973. A ressurgência em Cabo Frio. IPqM - Ministério da Marinha 78: 1-56.

Moreno, M. R.; Nascimento, M. T. \& Kurtz, B. C. 2003. Estrutura e composição florística do estrato arbóreo em duas zonas altitudinais na Mata Atlântica de encosta da região do Imbé, RJ. Acta Botanica Brasilica 17: 371-386.

Oliveira-Filho, A. T \& Fontes, M. A. L. 2000. Patterns of floristic differentiation among Atlantic forests in southeastern Brazil, and the influence of climate. Biotropica 32(Suppl): 1-16.

; Tametrão-Neto, E.; Carvalho, W. A. C.; Werneck, M.; Brina, A. E.; Vidal, C. V.; Rezende, S. C. \& Pereira, J. A. 2005. Análise florística do compartimento arbóreo de áreas de Floresta Atlântica sensu lato na região das Bacias do Leste (Bahia, Minas Gerais, Espírito Santo e Rio de Janeiro). Rodriguesia 56: 185-235

Penha, H. 1999. A synthesis of the geology of east fluminense coast, state of Rio de Janeiro, Brazil. In: Knoppers, B. A.;
Bidone, E. D. \& Abrão, J. J. (eds.). Environmental geochemistry of coastal lagoon system of Rio de Janeiro, Brazil. Série Geoquímica Ambiental 6: 3-10.

Pennington, R. T.; Lavin, M.; Prado, D. E.; Pendry, C. A.; Pell, S. K. \& Butterworth, C. A. 2004. Historical climate change and speciation: neotropical seasonally dry forest plants show patterns of both Tertiary and Quaternary diversification. Philosophical Transactions of The Royal Society - Biological Sciences 359: 515-38. ; Prado, D. E. \& Pendry C. A. 2000. Neotropical seasonally dry forests end Quaternary vegetation changes. Journal of Biogeography 27: 261-273.

Pessoa, S. V. A. \& Oliveira, R. R. 2006. Análise estrutural da vegetação arbórea em três fragmentos florestais na Reserva Biológica de Poço das Antas, Rio de Janeiro, Brasil. Rodriguésia 57: 391-411.

Prado, D. E. 2000. Seasonally dry forests of tropical South America: from forgotten ecosystems to a new phytogeographic unit. Edinburgh Journal of Botany 57: 437-461. \& Gibbs, P. E. 1993. Pattern of species distribution in the dry seasonal forests of South America. Annals of the Missouri Botanical Garden 80: 902-927.

Prance, G. T. 1982. Forest refuges: evidences from woody angiosperms. In: Prance, G.T. (ed.). Biological diversification in the tropics. Columbia University Press, New York. Pp. 137-156.

RADAMBRASIL. 1983. Folha S.F. 23/24 Rio de Janeiro/Vitória. Levantamento de recursos naturais. MME-SG/Projeto RADAMBRASIL, Vol. 32. Rio de Janeiro.

Rizzini, C. T. 1997. Tratado de fitogeografia do Brasil. $2^{\mathrm{a}}$ ed. Âmbito Cultural, Rio de Janeiro.

Rocha, C. F. D.; Bergallo, H. G.; van Sluys, M.; Alves, M. A. S. \& Jamel, C. E. 2007. The remnants of restinga habitats in the Brazilian Atlantic Forest of Rio de Janeiro State, Brazil: habitat loss and risk of disappearance. Brazilian Journal of Biology 67: 263-273. 
Sá, C. F. C 1992. A vegetação da restinga de Ipitangas, Reserva Ecológica Estadual de Jacarepiá, Saquarema (RJ): fisionomia e listagem de Angiospermas. Arquivos do Jardim Botânico do Rio de Janeiro 31: 98-102. 1996. Regeneração de uma área de floresta de restinga na Reserva Ecológica Estadual de Jacarepiá, Saquarema/RJ: I extrato herbáceo. Arquivos do Jardim Botânico do Rio de Janeiro 34: 621-632. 2002. Regeneração de um trecho de floresta de restinga na Reserva Ecológica Estadual de Jacarepiá, Saquarema, estado do Rio de Janeiro: II - extrato arbustivo. Rodriguésia 53: 5-23. 2006. Estrutura, diversidade e conservação de angiospermas no Centro de Diversidade de Cabo Frio, RJ. Tese de Doutorado. UFRJ, Rio de Janeiro. \& Araujo, D. S. D. 2009. Estrutura e florística de uma floresta de restinga em Ipitangas, Saquarema, Rio de Janeiro, Brasil. Rodriguésia 60(1): 147-170.

Scarano, F. R. 2006. Plant community structure and function in a swamp forest within the Atlantic rain forest complex: a synthesis. Rodriguésia 57: 491-502.

Silva, G. C. \& Nascimento, M. T. 2001. Fitossociologia de um remanescente de mata sobre tabuleiros no norte do estado do Rio de Janeiro (Mata do Carvão). Revista Brasileira de Botânica 24: 5162.

Silva, L. C. \& Cunha, H. C. S. 2001. Geologia do estado do Rio de Janeiro. $2^{\text {a }}$ ed. CPRM, Brasília.

Turcq, B.; Martin, L.; Flexor, J. M.; Suguio, K.; Pierre, L. C. \& Tasayaco-Ortega, L. 1999. Origin and evolution of Quaternary coastal plain between Guaratiba and Cabo Frio, State of Rio de Janeiro, Brazil. In: Knoppers, B. A.;
Bidone, E. D. \& Abrão, J. J. (eds.). Environmental geochemistry of coastal lagoon system of Rio de Janeiro Brazil. Série Geoquímica Ambiental 6: 25-46.

Ule, E. 1967. A vegetação de Cabo Frio (1901. Die vegetation von Cabo Frio and der küste von Brasilien. Botanischen Jahrbüchern 28: 511-528). Boletim Geográfico 200: 21-32.

UNESCO. 1973. International cartography and classification of vegetation. Ecology and Conservation 6. UNESCO, Paris.

Ururahy, J. C.; Collares, J. E. R. \& Santos, M. M. 1987. Nota sobre uma formação fisionômica-ecológica disjunta da estepe nordestina na área do pontal de Cabo Frio, RJ. Revista Brasileira de Geografia. 49: 25-9.

; Collares, J. E. R.; Santos, M. M. \& Barreto, R. A. A. 1983. Vegetação - As regiões ecológicas, sua natureza e seus recursos econômicos. In: Levantamento de recursos naturais, Folha SF 23/24 - Rio de Janeiro/Vitória. MME/SG/Projeto RADAMBRASIL. Vol. 32. Rio de Janeiro. Pp. 553-623.

Veloso, H. P. \& Goes-Filho, L. 1982. Classificação fisionômico-ecológica da vegetação Neotropical. Boletim Técnico Projeto RADAMBRASIL, Série Vegetação, № 1. Salvador.

; Rangel Filho, A. L. R. \& Lima, J. C. A. 1991. Classificação da vegetação brasileira, adaptada a um sistema universal. IBGE, Rio de Janeiro.

Walter, H. 1986. Vegetação e zonas climáticas: tratado de ecologia global. EPU, São Paulo.

Whittaker, R. H. 1978. Classification of plant communities. $2^{a}$ ed. Junk, The Hague.

Zonneveld, I. S. 1995. Land ecology. SPB Academic Publishers, Amsterdam. 